\title{
TOURISM AS A PUZZLE IN THE PROCESS OF IMPROVEMENT OF CREATIVE ECONOMY
}

\author{
Nikica Radović, \\ Danica Čigoja Piper
}

Singidunum University, Belgrade, Serbia
Correspondence: Nikica Radović

\begin{abstract}
:
This paper attempts to perform the analysis of the role of tourism in the process of strengthening the creative economy. Creative economy is defined as a specific approach to development of the economy based on the synergy of economy, culture and technology. It aims to improve the economic and sustainable development of the country and link various creative industries (design, discography, media, cinema, publishing etc.) through their commitment and contributions so as to achieve favourable results. Having in mind the strength of tourism as an economic activity, in terms of generated revenues and the number of employed population, it is important to analyze this segment of economy and highlight the tourism share in development of creative economy and sustainable development. The authors shall attempt to explain the impact of tourism on the development of state economy and the role of creative economy in the tourism field.The paper shall also elaborate on the effects of creative economy on the position and tourism destination recognition.
\end{abstract}

\section{Keywords:}

creative economy, tourism, creative industry, destination competitiveness.

\section{INTRODUCTION}

The concept of "creative economy" was developed by a British analyst and theorist John Howkins (2001). He introduced it into contemporary theoretical flows with an argument presented in the book titled "Creative Economy - How People Earn on Ideas" emphasizing three main elements of creative economy: creativity as an idea that can be economically valorized; creative products are the result of creative work and creative activity (Mikić, 2008).

Creative economy represents the unbreakable bond between creativity and economy, with the possibility to valorise the value of created products as the economic good or service. According to the report of the UNESCO (2013), creative economy is based on the share and exchange of cultural values, tradition, knowledge and skills between the creator (the producer) and the user (consumer). Creative economy is treated as the mixture of art, science and technology with the formation of a number of creative industries within it.

Creative industries represent a number of occupations based on skills, talents and creativity and they include: architecture, design, publishing, communication technologies, fashion, film, video and photography, software, 
computer games, toys, music, visual and performing arts, crafts, advertising, radio, television, and according to the UNESCO report, in some countries, cultural tourism as well (Jovičić \& Mikić, 2006., p.18). It is interesting to mention that culture and creative industry are sometimes intertwined. This particular connection is what opens the possibility for strengthening the creative sector in numerous economic fields, mostly in the tourism sector.

Today's creative industries are taking hold of and are becoming the initiator of economic development in numerous countries owning to the specific functioning of these industries, as well as fast development of creative activities. Namely, in these business areas, production is based on creativity and inspiration, following the "just-in-time" principle. Economic contribution of creative industries is reflected in a number of economic and non-economic effects, such as: export revenue, new job openings, development of information-communication technologies, strengthening of collectivism, creating the individual opinion, branding the area etc.

The contribution of creative economy on every level is reflected in US $\$ 2.250$ billion, thus the cultural and creative industry make 3\% of the world GDP and employ 29.5 billion people worldwide (EY, 2015, p. 8). According to the UNCTAD report for the year 2012, creative economy actively participates in the inclusive development, and green industries are also important participants of the creative economy, which participate in the encouragement of differences in terms of culture, ideas and democratic attitudes and contribute to ensuring sustainable development. As a response to the growing importance of the creative economy and its occupations, certain countries have formed ministries responsible for this area. One such example is Indonesia where the Ministry of Tourism and Creative Economy was formed, led by the attitude that the economy, culture, arts and heritage are inextricably connected (Nirwandar, 2012).

\section{THE SYNERGY OF TOURISM AND CREATIVE ECONOMY}

The concepts of creative economy and tourism development are closely related. The essence of tourism is travelling, stay and experience with certain amount of expenditure. According to the UNWTO (2016), the share of tourism in the world GDP is $10 \%$, and every eleventh citizen of the world is employed in the tourism industry. In 2015, international tourism revenue reached US $\$ 1,260$ billion. When it comes to exports, tourism holds the third place in the world, right after the export of fuels and chemicals and before the export of food and car products. In many countries, tourism assumes the first place in terms of exports (UNWTO, 2016). It is expected that this sector shall record considerable improvements in the following twenty years. At the same time, it is estimated that these will be the decades in which tourism will be the main initiator of economic growth, investments, general improvement in the society and environmental sustainability (Petkovic \& Pindzo, 2012). Such developmental path includes the involvement of tourism in the development of creative economy, on both national and global level, and the return benefit which will be reflected in the influence of the stronger creative sector on ensuring stable tourism development.

Tourism as a profession has the fastest growing index with a great potential for further growth and new investments, no matter which world destination is considered. With the possibility to attract new investments, tourism is the business sector which can rapidly activate new job openings and engage people of various professions. With the development of tourism and regular activities in this economic field, significant monetary funds are collected. Tourism has both direct and indirect effects on the development of the rest of the economy on the destination and its direct environment. Having in mind its importance for the destination to be equipped with adequate infrastructure - to have good roads, well supplied shops, developed IT network and support. Along with the development of the destination, some other branches such as traffic, commerce, telecommunication etc. get financed.

According to the statistical data of the Ministry of Trade, Tourism and Telecommunications of the Republic Serbia in 2015, foreign exchange inflow from tourism increased by $9 \%$, and it amounts $€ 945$ million. In the first quarter of 2016, foreign exchange inflow was $€ 252$ million.

Tourism offer can no longer rely solely on the traditional tourism patterns (travelling for mere holiday and relaxation purposes or sightseeing of certain landmarks without the specific theme). Namely, creative economy should foster new types of offer, which would enable tourism sector to experience fundamental changes stimulated by creative mechanisms.

Today, there are special forms of tourism that are becoming more and more interesting. Such is the so called thematic tourism which encompasses cultural tourism, city tourism, village tourism, eco tourism, health tourism and similar forms of tourism offer. In every form of thematic tourism, it is possible and desirable to use one's own inspiration, ideas and talents which indicate a strong connection between tourism and creative econo- 
Table1. Foreign exchange inflow from tourism in the Republic of Serbia

\begin{tabular}{ccc}
\hline Year & In millions of Euros & In millions of US\$ \\
\hline 2011 & 710 & 992 \\
\hline 2012 & 708 & 906 \\
\hline 2013 & 792 & 1,053 \\
\hline 2014 & 863 & 1,139 \\
\hline 2015 & 945 & 1,048 \\
\hline I quarter 2016 & 252 & 280 \\
\hline
\end{tabular}

Source: Ministry of Trade, Tourism and Telecommunications of the RS

my. This connection is most pronounced when it comes to cultural and city tourism.

City tourism is one of the tourism segments which records constant growth, and such movements are influenced by the growing urbanization of the world population, which is in search for new findings and experience. Tourists in the cities can spend time in various ways. Thus, depending on singularity, position and role, the country forms types of world metropolis such as national capital cities, cultural capital cities, artistic cities, cities under the protection of UNESCO, creative, industrial, sport-oriented, festival and futuristic cities (Jovanović, 2015).

"The Network of Creative Cities" is the project UNESCO which refers to cities - places which can enable technology, talent and tolerance, and in return there is economic growth, i.e., the growth of the business results.The idea is that, besides promotions, creative cities can exchange experience, obtain new knowledge. "The Network of Creative Cities" consists of cities thematically organized in the cities of crafts, literature, music, gastronomy, music, sport and other specific fields of interest of modern tourists.

Cultural tourism is the primary form of tourism of special interests and it refers to learning about other people, their habits, customs, tradition and the way of living. The most frequently visited objects are the museums which are following curatorial trends more and more on the global level and are preparing more and more attractive contents (the inflow of new technologies is also noticeable, as well as the invitation for visitors to start the interaction with the setting). Great world exhibition spaces are not the only that provide active contribution to development of cultural tourism - cultural institutions and tourism workers in Serbia are more and more engaged in work based on creative expression. The settings that are currently popular and interesting in Belgrade are the exhibition on the life and work of Mihajlo
Pupin in the Historical Museum of Serbia in Belgrade, as well as the exhibition on life and work of Nikola Tesla in the Museum of Nikola Tesla. Both exhibitions follow the aforementioned global tendencies when preparing the exhibitions and thus present the mixture of historical buildings, culture, design and information technologies, which have a considerable impact on the appeal of the programme for local and foreign tourists, and therefore influence the attendance level.

Creative sector development in tourism was particularly supported by the United Nations. UNESCO is the organization of the United Nations which deals with cooperation in the field of education, science and culture. In their work, UNESCO handles cultural legacy and forms the list of the world heritage. That list includes five sites from Serbia: Old Ras and Sopoćani (since 1979), Studenica Monastery (since 1986), Medieval Monuments in Kosovo and Metohija (since 2004 and 2006), Gamzigrad - Romuliana, Palace of Galerius (since 2007) and Stećci Medieval Tombstones Graveyards (since 2016). The wealth with cultural content and legacy is possible to use and realize in the flows of creative economy on the national level. The examples are the projects "Refreshing Memory" and "Easter Egg" (Čigoja \& Radović, 2014) where with the fragments from national culture and traditions, that is, with the illustrations from monasteries usable elements can be created and by selling them, certain income can be obtained. At the same time, a certain mark of history or cultural legacy of a country is visible.

Another interesting project is EU project "European Capital of Culture", which is organized with the aim of presenting cultural life and the domain of city culture. Undoubtedly, it should lead to certain economic gain. According to the report of the consulting agency "Palmer Rey" hired by the European Commission to analyze the capitals of culture for the period from 1985 to 2003, the results pointed out that for this type of promotion, the return on every euro invested has gone up from $€ 8$ to $€ 15$. At the same time, with the growth of income 
comes the growth of the number of tourists. Accordingly, with the help of this strategy, Copenhagen noted the growth of tourists by $11 \%$, the city of Sibiu increased the percentage of visits by $32 \%$, and the well-known Belgian city of Briz stored $€ 213$ million (Jasarović, 2015).

Becoming aware of the potential of the connection of creative economy and tourism opens the question of development of new possibilities for cooperation of creative industries and tourism industry. Therefore, it is necessary for cooperation among inter-sectors to be as strong as possible, in the private sector, as well as the stimulation by the country. Governments play an important role in encouraging the development of creative tourism of the given country, including the development of necessary infrastructure, as well as strengthening of creative clusters in the economy (OECD, 2014). The usage of new technologies confirmed useful knowledge about the primary (tourist) field and inevitable cooperation with the creative sector represent obligatory elements of contemporary tourism development. In the information age characterized by almost immeasurable number of appealing contents, travel agents are supposed to tell an adequate story in the most appealing way and offer the most attractive content to meet the expectations of a great number of tourists. Moreover, it is the creative economy that enables the realization of this goal.

\section{CONCLUSION}

The growth of creative economy leads to the advancement of socio-economic growth of commerce and innovations. Through the exchange of national experience and implementation of certain strategies, it is possible to achieve even greater growth of creative economy. The programs of creative cities, European capitals and items on the UNESCO list influence the development and positioning of destinations, the level of tourist attendance, and thus the increase in income. In this way, the reciprocal relationship of tourism and creative economy is once again implied. Their connection is imminent and quite necessary in the $21^{\text {st }}$ century. It is virtually impossible to imagine tourism development without the inflow of positive impulse and active development of creative tourism. The mere concept of tourism is creative, as this branch of industry draws various pieces of information from different historical, cultural and social patterns and combines them in their own unique way. In this way, creativity is generated, which encourages not only tourism sustainability and rise, but also creative economies as such.

\section{REFERENCES}

Čigoja, D., \& Radović, N. (2014). Uloga digitalnog marketinga u očuvanju kulturno-istorijske baštine Srbije. Impact of Internet on Business Activities in Serbia and Worldwide / Singidunum University International Scientific Conference Sinteza 2014. Beograd: Univerzitet Singidunum. doi:10.15308/ SInteZa-2014-292-294

Ernst \& Young. (2015). Cultural Times: The first global map of cultural and creative industries. Retrieved August 27, 2016 from http://www.ey.com/Publication/vwLUAssets/ey-cultural-times-2015/\$FILE/ ey-cultural-times-2015.pdf

Jasarović, E. (2015). Strategije razvoja lokalne kulturne politike u Crnoj Gori sa aspekta kreativne ekonomije gradova: doktorska disertacija. Beograd: FDU.

Jovanović, V. (2015). Tematski turizam. Beograd: Univerzitet Singidunum.

Jovičić, S., \& Mikić, H. (2006). Kreativne industrije. Beograd: British Council.

Mikić, H. (2008). Kreativne industrije, dizajn i konkurentnost: proaktivan pristup. Beograd: CEI.

Nirwandar, S. (2012). Indonesia Tourism: Policy and Strategy, VII Tourism Ministerial Meeting 2012. Russia: Khabarovsk.

OECD. (2014). Report: Tourism and the Creative Economy. OECD: Paris.

Petković, G., \& Pindžo, R. (2012). Turizam i novi ekonomski izazovi. Ekonomika preduzeća, 60(1-2), 117-126. doi:10.5937/ekopre1202117P

UNCTAD Report (2012). Geneva, Switzerland

UNESCO Report (2013). New York: UN

UNWTO Tourism Highlights (2016).

http://www.e-unwto.org/doi/book/10.18111/97

89284418145,preuzeto 05.08.2016. 